Uniwersytet Kazimierza Wielkiego w Bydgoszczy

Wydział Humanistyczny

Instytut Neofilologii i Lingwistyki Stosowanej

tel.: +48523411797

e-mail: famielk@poczta.onet.pl

\title{
Урбанонимная система межвоенного Бреста-над-Бугом
}

Ключевые слова: названия улиц (годонимы), межвоенный город, Брест-над-Бугом.

Данная статья, которая вписывается в русло исследований по урбанонимии польско-восточного пограничья, преследует две основные цели: во-первых, ввести в научный обиход факты, относящиеся к урбанонимной картине Бреста-над-Бугом, и, во-вторых, на основе этого определить основные тенденции внутригородской номинации обозначенного периода.

Ономастикон интересующего нас региона становился объектом исследования в работах многих авторов, которые сосредоточивали свое внимание на отдельных аспектах годонимии, например: исторические названия гродненских улиц [Szcześniak 2002, 81-100], польские элементы в урбанонимии современного Львова [Denda 2008, 541-548], современные названия улиц Бельска-Подляского [Hordań 2010, 293304], польско-украинское пограничье на примере урбанонимии Львова и Пжемышля [Денда 2012], картина городского общества, отраженная в урбанонимии Гродно XVI-XVIII вв. [Citko 2010, 373-382].

Среди ономастических исследований определенное место занимают работы, относящиеся к урбанонимии Бреста, в частности те, которые посвящены проблемам названий внутригородских объектов, например: Семантычныл тыпь ўрбанонімаў г. Брэста [Якубук 2003, 
159-161], Analiza semantyczna urbanonimów Brześcia w ujęciu historycznym [Famielec 2006, 187-195], Лексико-семантический аспект наименований брестских внутригородских объектов [Famielec 2008, 231-234], Наименования брестских линейных объектов в послевоенный период [Famielec 2009, 270-275], Переименования брестских линейных объекmов (1939-1941 г2.) [Famielec 2006, 361-364], Zmiany w nazewnictwie ulic Brześcia (lata 1941-1944) [Famielec 2007, 157-162].

Относительно небольшое количество публикаций предопределяет наличие вопросов, которые до сих пор не нашли надлежащего научного освещения. Одним из них является обозначенная в заглавии статьи урбанонимная система межвоенного города, когда он оказался с 9 февраля 1919 г. ${ }^{1}$ в границах польского государства. Принадлежность Бреста к Польше подтвердил мирный договор, подписанный 18 марта 1921 г. в Риге, а постановление Министерства внутренних дел от 12 февраля 1923 г. повлекло за собой переименование города в Брест-над-Бугом ${ }^{2}$ (Brześć nad Bugiem) [Ващукувна-Каменецка 2000, 93]. Следующим шагом новой администрации было переименование ряда городских улиц [Розенблат 2009, 6].

Источниками онимического материала послужили 9 актовых документов, находящихся на постоянном хранении в Государственном архиве Брестской области ${ }^{3}, 2$ списка улиц, помещенные в изданных го-

1 Освобождение города, оккупированного немецкими войсками во время советско-польской войны, началось, когда в Брестскую крепость вошел 22-й пехотный полк оперативной группы генерала Антония Листовского. В то же время в городе шли бои между отступающими немецкими войсками, когда которых командир отряда капитан Владислав Стецкевич был сражен немецкой пулей [Ващукувна-Каменецка 2000, 91].

2 Многочисленные переименования города анализировались в статьях, см. Н.Р. Якубук; M. Famielec 2006, с. 187-195; M. Kondratiuk, Elementy kultury wschodniosłowiańskiej w urbanonimii miasta Kołobrzeg-Podczele w województwie zachodnipomorskim, [в:] Polsko-białoruskie zwiazki językowe, literackie, historyczne, kulturowe. Materiaty XIV Międzynarodowej Konferencji Naukowej „Droga ku wzajemności” (Grodno 26-27.10 2006), S. Musijenko i I. Kreń (ред.), Grodno 2007, с. 18-23.

3 Указание Брестской городской рады о благоустройстве гор. Бреста; Регламент Брестской городской бойни и устав водопроводно-канализачионных предприятий (14 августа 1919 г.), [в:] ГАБО, Ф. Р-5, оп. 1, д. 4, на 42 листах; Заявления жителей города Бреста о выдаче свидетельств на право владения движимьм и недвижимьм имуществом с приложением последних (16 февраля 1921 - 16 октября 1921), [в:] ГАБО, Ф. 5, оп. 1, д. 22, на 224 листах; Списки улич гор. Бреста, владельчев домов и квартир в г. Бресте (начато 1923 г.-1932 г.), [в:] ГАБО Ф. 5, оп. 1, д. 2104, л. 1; Протоколь опроса свидетелей по установлению постоянного местожительства граждан гор. Бреста (13.07-27.07.1922), [в:] ГАБО, Ф. 5, оп. 1, д. 25; Wykaz ulic miasta Brześcia nad Bugiem, [в:] ГАБО, Ф. 5, оп. 1, д. 5419, л. 1; Bыписка из протокола заседания Высоко-Литовского магистрата, инструкиия о ревизии 
родским магистратом материалах: Rocznik miasta Brześcia na rok 19304 и Informator miasta Brześcia $1936 r .^{5}, 4$ карты города ${ }^{6}$ В итоге собрано 139 онимических единиц.

Материал, анализируемый в настоящей статье, подвергается лексико-семантической и структурной классификации, предложенной K. Хандке ${ }^{7}$. На ее основании выделяются такие типы номинациий внутригородских объектов, как:

1) отонимные названия, восходящие к собственным именам:

а) наименования, образованные от антропонимов: Batorego, Bema /Bema Gen. Józefa/Gen. Bema, Dábrowskiego/Jerzego Dabrowskiego, Hallera/Koszary Gen. Hallera/Hallera Kosz., Kilińskiego/Kilińskiego Jana, Kościuszki, Kraszewskiego, Listowskiego/Jenerala Listowskiego, Mickiewicza, Narutowicza/Narutowicza Gabryela, Orzeszkowej, Pereca, Pierackiego, Piłsudskiego/Piłsudskiego Plac/Piłsudskiego Pl./Plac Marsz. Piłsud-

гмин и списки населенных пунктов Брестского повета. List zaadresowany Do Pana Starosty pow. Brzeskiego (30 I/23 r.). W odpowiedzi na pismo z dnia 23/I r.b. NIV303/I Wydziat Gospodarczy przy Magistracie m. Brześcia, poniżej tego przesyła wykaz ulic $w$ m. Brześciu z nowymi i dawnymi nazwami, [в:] ГАБО, Ф. 2, оп. 1, д. 208, л. 43-44; Ogloszenie Magistratu brzeskiego o wydawaniu od dnia 11 stycznia 1921 kartek aprowizacyjnych dla ludności izraelickiej. Объявление Брестского магистрата о выдаче продовольственньх карточек жителям города иудейского вероисповедания. Не позднее 11 января 1921 г., [в:] ГАБО, ф. 5. оп. 1, д. 108, л. 40; Циркуляры, декретьи и распоряжения комиссара Брест-Литовского пов. (подлинники и копии) и переписка с ними об открытии торгово-промышленных предприятий, взимании налогов с населения и др. хозяйственным вопросам; сведения о посевах сельскохозяйственных культур и окрестности гор. Бреста в 1918-1919 ге. Списки коммунальных предприятий и улич гор. Бреста. Список переименованных магистратом улич г. Бреста с указанием их довоенных названий 26 VI 1919. Wykaz nazw wszystkich ulic w Brześciu Litewskim z wyszczególnieniem zmiany nazw poprzednich na teraźniejsze, [в:] ГАБО, Ф. 5, оп. 1, д. 2, л. 186; Szkic m. Brześcia N Bugiem "Przedmieście Kijowskie” (Zaludnienie ulic) 1930 r., [в:] ГАБО, Ф. 5, оп. 1, д. 859, л. 2.

4 W. Mondalski (red.), Brześć nad Bugiem 1929, c. 206-209.

5 Brześć nad Bugiem 1936, c. 28-29.

6 Plan Brześcia - 1939, [в:] Д. Ващукувна-Каменецка, 2000, Брест - город незабываемьй, Брест, с. 113; Plan miasta Brześcia N/B ze wskazaniem administracyjnych granic ustalonych Rozporzadzeniem Mnisterstwa Spraw Wewnętrznych z dnia 15-XI-1933 r. /Dz.U.R.P. № 93 poz. 716/ Rozporzadzeniem Rady Ministrów z dnia 28-XI-1933 r. /Dz.U.R.P. № 94 poz. 719/ skala 1:10 000, [в:] ГАБО, ф. 5, оп. 1, д. 859, л. 4; Orjentacyjny Plan miasta Brześcia n/B., Podziałka 1:15 000 litografia B. Lulkin, Brześć n. B., ul. Jagiellońska 63. Nakład: Kasy Samopomocy Pracowników Szpitala Kolejowego w Brześciu n. B., [inter 1922 et 1939] wraz z indeksem nazw na verso, http://polona.pl/ search/83f6a7c0-7331-11e5-843d-51949449da13/; Plan miasta Brześcia n/B. 1:10 000 [non post 1939] http://polona.pl/item/22245765/0/

7 K. Handke, 1992, Polskie nazewnictwo miejskie, Warszawa.

8 Через значок «/» приводятся варианты записи урбанонимов, встречаемые в актовых материалах. 
skiego/Plac Dumski/Koszary Marszałka Pitsudskiego, Pułaskiego/K. Putawskiego/Kazimierza Pułaskiego, Rejmonta, Sienkiewicza, Stawa Zwierzyńskiego/Stawa Zwierz., Stowackiego, Sobieskiego, Staniewicza/Ks. Staniewicza, Steckiewicza/Kap. Steckiewicza, Szeptyckiego, Traugutta, Wigury, Zajdla, Zamojskiego/Zamojskiego Jana, Zygmuntowska, Żwirki), в том числе и связанные с представителями королевской власти (Jagiellońska);

б) образованные от топонимов, в том числе от ойконимов (Adamkowska, Białostocka, Czernawczycka, Grajewska, Kobryńska, Kowelska, Poleska, Rewelska, Szpanowiecka, Tryszyńska, Wotyńska, Żytomierska) и гидронимов (Muchawiecka - от названия реки Mухавеu);

2) отапеллятивные наименования:

a) наименования, образованные от номинаций разных городских близлежащих объектов (Aleja Forteczna, Bazarna, Bracka - от Братская церковь), Bracki Zautek, Browarna, Dworcowa, Gimnazjalna, Gimnazjalny Zautek, Hale Targowe, Koszarowa, Lotnicza, Mięsny Zaułek (от названия продукта, которым торговали в переулке), Mikołajewska-Dluga (от Свято-Николаевская церковь), Przemystowa, Soborna, Soborny Zautek, Szlachtuzowa (от нем. Schlachthaus 'убойня'; schlachten 'убивать скот' + Haus 'дом'9), Szpitalna, Tartaczna, Teatralna, Zacmentarna);

б) «природные» годонимы, происходящие как от флористических названий (Brzozowska, Chmielna, Kasztanowa Aleja, Klonowa, KrótkoBrzozowska, Nowo-Kasztanowa, Orzechowa, Owocowa, Sadowa, Topolowa, Wierzbowa, Wiśniowa, Zielna), так и от номинаций животных (Rysia, Ścieżka Wołowa, Wronia, Żabia, Żórawia);

в) онимы, образованные названиями лица/лиц по статусу, как представителя определенной общности людей (Harcerska, Mieszczańska, Senatorska, Hetmańska, Legionów, Ułańska);

д) указывающие на: местоположение относительно природного (Brzegowa, Lakowa, Nadbrzeżna, Polna, Rzeczna) или созданного человеком объекта (Dojazd, Graniczna, Kolejowa, Nadkolejowa, Przejazd, Skkadowa, Strzelecka), а также - на выполняемую функцию (Wojewódzka);

е) наименования, указывающие на свойства и качества внутригородского объекта, в том числе - его размер (Ciasna, Mała, Niska, Średnia, Wielka), конфигурацию объекта (Krzywa, Niecała, Prosta, Ukośna, Urwa$n a)$, пространственные параметры (Dluga, Krótka, Szeroka), цвет, на базе которого сформированы названия (Bronzowa, Jasna, Szara, Zielona), расположение относительно частей горизонта (Południowa, Pólnocna,

9 W. Kopaliński, 1994, Stownik wyrazów i zwrotów obcojęzycznych, Warszawa, c. 494. 
Wschodnia, Zachodnia), ланшафт, его растительность (Błotna, Ogrodowa, Zbożowa, Żytnia); а также метафорические названия (Cicha, Chtodna, Dobra, Miła, Nadzieja, Niezależna, Piękna, Przeskok, Smutna, Spokojna, Sportowa, Wesoła, Wiejska, Wolna, Wolności Aleja, Wspólna, Wygodna, Zgoda);

ж) связанные с историческими событиями (3-go Maja/Trzeciego Maja, 9-go Lutego/Dziewiatego Lut., 11-go Listopada/Jedenastego List., Aleja Unii Lubelskiej/Unji Lubelskiej/Lubelska).

Анализируемые онимы, являющиеся результатом многочисленных переименований, дают представление об урбанонимной системе, сложившейся в польском городе над Бугом. В ней доминируют годонимы, в основе которых лежат как имена людей, значимые для Польши, так и даты, события, важные для польской исторической памяти.

Так, в честь февральских событий 1919 г. Вознесенской уличе 10 было присвоено имя капитана польской армии, Владислава Стецкевича, погибшего в сражении за Брест 9 февраля 1919 года, - и она стала называться Steckiewicza. В память о тех днях еще две улицы получили новые наименования: улица Збироговская ${ }^{11}$, существовавшая с первой половины XIX в., была переименована в честь генерала Антония Листовского - Listowskiego, а улица (точнее, объединение двух) Миллионная-Поличейская ${ }^{12}$ получила имя майора польской армии Ежи Домбровского - Dabrowskiego [Сарычев 2006, 55]. Одна из важнейших транспортных магистралей центра города - улица Дворянская ${ }^{13}$ [Шамякин 1987,263$]$ была переименована в честь всемирно известного уроженца Брестчины, польского поэта, основоположника польского романтизма в поэзии, общественного деятеля, публициста, просветителя Адама Бернарда Мицкевича (1798-1855) и стала называться Mickiewicza. Улица Московская поменяла свое название на Sienkiewicza,

10 От названия объекта Вознесенская церковь, расположенного на именуемой улице [Мезенко 2003, 102].

11 От названия населенного пункта Збироги [Мезенко 2003, 102].

12 На улице располагались магазинчики, лотки, различные ремесленные мастерские, владельцами которых чаще всего являлись евреи. Кроме торговых учреждений на улице располагались правительственные и общественные здания магистрата, городской управы и думы, полицейское управление, канцелярия, здесь проживал и полицмейстер. Возможно, поэтому улица вскоре стала Полицейской [Купцова 2007, 106, 108].

13 На улице возводились, главным образом, особняки важных государственных чиновников. Первые здания были построены в 30-40 гг. XIX в. в связи с появлением крепости [Купцова 2007, 63]. 
увековечивая память всемирно известного польского писателя, лауреата Нобелевской премии Генрика Сенкевича (1846-1916). В честь великого князя литовского (с 1506) и короля Польши (с 1507) Зигмунта I Старого, предпоследнего из династии Ягеллонов, в 1919 г. улица Славянская-Медовая стала именоваться Zygmuntowska. Имя королевской династии в Польше (1386-1572 гг.), Великом княжестве Литовском в (1377-1401 гг.), Венгрии (1440-1444 гг., 1490-1526 гг.) и Чехии (1471-1526 гг.), основателем которой был Владислав Ягайло (Ягелло) [Мезенко 2003, 282], стало мотивирующим для названия улицы Jagiellońska, которая до 1919 г. называлась Шоссейная. Память о руководителе Польского восстания 1794 г., государственного и военного деятеля, участника войны за независимость Соединенных Штатов Америки (1776-1783) Анджея Тадеуша Бонавентуры Костюшко (1746-1817) [Sienkiewicz 1991, 79] сохранена в номинации улицы Kościuszki, которая до 1921 г. была Гоголя в честь русского писателя Н.В. Гоголя. От имени Яна Собеского (1629-1696), крупного польского полководца, польского короля (Ян III) и с 1674 г. великого князя литовского, получила свое новое наименование улица Широкая - с 1921 г. Sobieskiego. В его правление, ознаменовавшееся затяжными войнами с Османской империей, Речь Посполитая в последний раз пережила взлет как европейская держава [Sienkiewicz 1991, 57]. В честь политика, министра внутренних дел Польши (с 1931 г.), полковника Бронислава Перацкого (1895-1934), убитого украинскими националистами в июне 1934 г., улицу Кривую переименовали в улицу Pierackiego [Купцова 2007, 85]. Имя классика еврейской литературы на идише, общественного деятеля, оказавшего значительное влияние на развитие еврейской литературы и еврейской культуры дооктябрьского периода, Ицхока Лейбуша Переца (1851-1915) [В. Petrozolin-Skowrońska 1997, 548] увековечено в новом названии улицы Тополёвая - ее стали называть Pere$c a$. В честь маршала Польши, первого руководителя возрожденного польского государства и основателя польской армии Юзефа Пилсудского (1867-1935) [Sienkiewicz 1991, 125], неоднократно побывавшего в Бресте в 20-30-е гг., была названа площадь - Pitsudzkiego. (У этого внутригородского объекта до 1922 г. были другие имена: улица Думская/Paтушная ${ }^{14}$ /Plac Ratuszowy). Улица Петровская, названная в честь царя Руси Петра I, в 1928 г. переименована в Batorego в честь

14 В 1913 г. на площади располагались городские дума и управа, ратуша, публичная библиотека-читальня имени Н.В. Гоголя, булочные, общество покровительства животных, работали судья и агент страхового общества [Тишук 2007, 102]. 
Стефана Батория (1533-1586), польского короля и великого князя литовского (с 1576). Имя Юзефа Захариаша Бема (1794-1850), польского генерала, полководца, участника Польского восстания (1830-1831) и революции (1848-1849) в Австрии и Венгрии, одного из командиров революционных войск в Трансильвании [Sienkiewicz 1991, 19], было увековечено в названии улицы Вета, которая ранее была Кирстовская улииа/Кирстовского улица [Мезенко 2003, 116]. С 1926 г. улица 9 Lutego (названа в память февральских событий 1919 г.) стала называться Mościckiego в честь президента Польши (1926-1939 гг.), государственного деятеля, ученого-химика, изобретателя, одного из создателей химической промышленности Польши - Игнация Мосцицкого (1867-1946) [Sienkiewicz 1991, 103].

Фамилии знаменитых поляков запечатлены и в ряде других переименованных урбанонимов. Так, улица Prezydjalna называлась улица Kilińskiego (до 1921 г.), в память о польском политическом деятеле и участнике восстания 1794 г. Яне Килинском (1760-1819). Бывшие $Z a$ ułki II, III, IV стали именоваться в честь польских писателей: Юзефа Игнация Крашевского (1812-1887), публициста, издателя, автора книг по истории и этнографии [В. Petrozolin-Skowrońska 1997, 548], - улица Kraszewskiego; Юлиуша Словацкого (1809-1849) - поэта и драматурга, относящегося, наряду с Адамом Мицкевичем, к величайшим польским поэтам эпохи Романтизма [B. Petrozolin-Skowrońska 1996, 895], - улица Stowackiego; Владислава Станислава Реймонта (1867-1925), писателя, лауреата Нобелевской премии по литературе 1924 года [В. Petrozolin-Skowrońska 1996, 523], - улица Rejmonta.

В урбанонимии межвоенного Бреста немало линейных объектов, названных в память: польского государственного деятеля из рода Замойских, Яна Замойского, основателя города Замосць в 1580 г., - улица Zamojskiego; революционера, генерала, лидера польского восстания 1863 г. Ромуальда Траугутта - улица Traugutta; активного участника этого восстания Людвига Нарбута, начальника восстания в районе Лиды, - улица Narbutta; польского генерала Юзефа Халера - улица Hallera; военного руководителя Слава Звежинского - улица Stawa Zwierzyńskiego - офицера I бригады польских легионов; генерал-майора австро-венгерской армии и генерала брони Войска Польского Станислава Щептицкого - улица Szeptyckiego; политика Габриэла Нарутовича - первого президента Польши - улица Narutowicza; писательницы белорусского происхождения Элизы Ожешко - улица Orzeszkowej; участника борьбы за свободу польского и американского народов - одного из руководителей и маршалка Барской конфедерации, генерала 
континентальной армии во время войны за независимость США Казимира Пулавского - улица Puławskiego; польских летчиков Францишка Жвирко - улица Wigury и Станислава Вигуры - улица Żwirki, а также священника - улица Staniewicza.

Четыре названия улиц межвоенного Бреста увековечивали важные для истории Польши события, памятные даты. В результате переименования в 1919 г. Бульварного проспекта появилось название Aleja Unji Lubelskiej, данное в честь международно-правового акта объединения Великого княжества Литовского с Польшей в федеративное государство Речь Посполитую, утвержденного в Люблине 1 июня 1659 г. [Mезенко 2003, 145]. В честь дня принятия 3 мая 1791 г. Четырехлетним сеймом Речи Посполитой первой польской конституции, которая вводила наследственную монархию, укрепляла центральную власть, ликвидировала конфедерацию, «liberum veto», остатки государственной Литвы [Мезенко 2003, 261], с 1919 г. часть улицы Пушкинской (одной из главных транспортных городских магистралей, с 1887 г. именовавшейся в честь русского писателя, родоначальника новой русской литературы и одного из создателей современного русского литературного языка А.С. Пушкина) стала называться улицей 3-go Маја. В ознаменование событий, произошедших 9 февраля 1919 г., когда закончилась эвакуация германских частей и в Брест вошел польский пехотный полк, вторая часть исторической улицы Пушкинской называлась 9-go Lutego (до 1926 г.). Наименование улицы 11-go Listopada (бывшая Maszewska), в свою очередь, напоминало о Дне независимости и дате окончания Первой мировой войны, после которой в стране начались перемены и восстановление государственности под руководством вернувшегося из германского плена Юзефа Пилсудского.

По структуре зафиксированные имена внутригородских объектов Бреста-над-Бугом представлены простыми и сложными наименованиями.

Наиболее продуктивными являются простые годонимы, состоящие из номенклатурного термина улииа 15 (единично выступают aleja, plac, ścieżka, zautek). Среди них нам удалось выделить следующие суффиксы: - 'a (Rysia, Wronia, Żurawia и т.п.), -н- (Browarna, Gimnazjalna, Szpitalna), -н'-(Średnia, Zachodnia, Żytnia), -ова- (Brukowa, Klonowa, Ogrodowa), -ck- (Adamkowska, Kobryńska, Muchawiecka). K префиксальным формам можно отнести названия Nadkolejowa и Zacmentarna.

15 Следует отметить, что номенклатурный термин улица в анализируемых записях полностью отсутствует. 
Сложные названия представлены, в свою очередь конструкциями с прилагательными: Nowokasztanowa, а также Krótko-Brzozowiecka, Nowo-Jagiellonska, Mikołajewska-Długa.

Подытоживая, стоит отметить, что:

1) в урбанонимной системе Бреста, вошедшему в состав польского государства, важное место занимают отантропонимные названия линейных объектов. Это еще раз подтверждает результаты исследований А.М. Мезенко [Мезенко 1991, 116-117], свидетельствующие о том, что в городах западной зоны нынешней Беларуси, в том числе в Бресте, преобладали годонимы, мотивированные именами польских государственных и военных деятелей (Batorego, Bema, Kilinskiego, Listowskiego, Sobieskiego), а также лидеров польского национального движения (Kościuszki, Piłsudskiego, Traugutta), польских писателей (Kraszewskiego, Mickiewicza, Orzeszkowej, Rejmonta, Sienkiewicza, Stowackiego) и др.;

2) о предыдущих этапах развития города свидетельствуют единичные названия улиц (Mikolajewska - Dtuga - на ней находилась церковь Св. Николая); высокий уровень идеологизированности данной онимной системы, ее зависимость от государственной политики Польши иллюстрируют, в первую очередь, мемориальные наименования брестских линейных объектов;

3) улицы с новыми, польскими именами располагались в центральной части Бреста, и их номинации, таким образом, занимали видное место в городском, в том числе лингвистическим, ландшафте.

Таким образом, урбанонимная система отдельного населенного пункта является фрагментом ономастической - и шире - языковой картины мира, хранителем экстралингвистической информации, включая историческую.

\section{Литература}

Ващукувна-Каменецка Д., 2000, Брест - город незабываемый, Брест.

Купцова В.Г., 2007, Я иду по городу, по знакомой уличе..., Путешествия по уличам довоенного и современного Бреста, Брест.

Мезенко А.М., 1991, Урбанонимия Белоруссии, П.П. Шуба (ред.), Минск.

Мезенко А.М., 2003, Имя внутригородского объекта в истории. Об урбанонимах Беларуси XIV - нач. XX в., Минск.

Розенблат Е.С. (гл. ред.), 2009, Брест в 1919-1939 г2. Документы и материальl, Брест. 
Сарычев В., 2006, В поисках утраченного времени, Кн. 1, Брест. Тишук П.Н. (общ. ред.), 2007, Улиць Бреста рассказывают..., Брест.

Шамякин И.П. (гл. ред.), 1987, Брест. Энииклопедический справочник, Минск. Якубук Н.P., 2003, Семантыцныл тыль ўрбанонімаў г. Брэста, [в:] Studia Russica XX, c. 159-161, Будапешт.

Citko L., 2010, Obraz społeczności miejskiej utrwalony w urbanonimii Grodna XVI-XVIII w., [в:] Nazwy własne a społeczeństwo, т. 2, c. 373-382, Łask.

Denda M.H., Pamięć miasta - elementy polskie w urbanonimii wspótczesnego Lwowa, [в:] Acta Polono-Ruthenica XIII, 2008, c. 541-548.

Denda M.H., Urbanonimia pogranicza polsko-ukraińskiego (na materiale nazw ulic i placów Przemyśla i Lwowa), Lublin 2012 (кандидатская диссертация).

Famielec M., Analiza semantyczna urbanonimów Brześcia w ujęciu historycznym, [в:] Polsko-białoruskie zwiazki jezykowe, literackie, historyczne, kulturowe. Materiaty XIII Międzynarodowej Konferencji Naukowej „Droga ku wzajemności” (Białystok 15-16 VII 2005), M. Kondratiuk, B. Siegień (red.), Białystok 2006, c. 187-195.

Famielec M., Zmiany w nazewnictwie ulic Brześcia (lata 1941-1944), [в:] Polsko-białoruskie zwiazki jezykowe, literackie, historyczne, kulturowe. Materiały XIV Międzynarodowej Konferencji Naukowej „Droga ku wzajemności" (Grodno 26-27 10 2006), S. Musijenko i I. Kreń (red.), Grodno 2007, c. $157-162$.

Famielec M., Переименования брестских линейных объектов (1939-1941 г2.), [в:] Acta Albaruthenica, Rossica, Polonica. VII міжнародная навуковая канферэнцья. Беларуска-русска-польскае супастаўляльнае мовознаўства, літаратуразнаўства, культуралогія. Зборнік навуковых артыкулаў, Г.М. Мезенка (ред.), Віцебск 2006, с. 361-364.

Famielec М., Лексико-семантический аспект наименований брестских внутригородских объектов, [в:] Славянские языки: системно-описательный и социокультурный аспекты исследования. Материаль III Международной научно-методической конферениии (Брест 22-23 ноября 2007), Е.И. Абрамова, Г.В. Писарук, О.А. Фелькина (ред. кол.), Брест 2008, c. $231-234$.

Famielec M., Наименования брестских линейных объектов в послевоенньии период, [в:] Польска-Беларускія Моўньля, Літаратурныля, Гістарычныля i Культурныля Сувязі. Матэрыяльи XV Міжнароднай навуковай канферэниьі «Шлях да ўзаемнасиі» (Grodno 13-14 XI 2008); I. Крэнь, С. Мусіенка, I. Папоў, Я. Роўба (ред. кол.), Гродна 2009, с. 270-275.

Hordań M., Współczesne typy nazw ulic Bielska Podlaskiego, [в:] "Studia Wschodniosłowiańskie", т. 10, 2010, c. 293-304.

Kondratiuk M., 2007, Elementy kultury wschodniosłowiańskiej w urbanonimii miasta Kolobrzeg-Podczele w województwie zachodnipomorskim, [в:] Polsko-białoruskie zwiazki jezzykowe, literackie, historyczne, kulturowe. Materiaty XIV Międzynarodowej Konferencji Naukowej „Droga ku wzajemności” (Grodno 26-27 10 2006), S. Musijenko i I. Kreń (ред.), Grodno, с. 18-23. 
Kopaliński W., 1994, Słownik wyrazów i zwrotów obcojęzycznych, Warszawa.

Petrozolin-Skowrońska B. (red.), 1995-1998, Nowa Encyklopedia Powszechna PWN, т. 1-6, Warszawa.

Sienkiewicz W., 1991, Stownik historii Polski, Warszawa.

Szcześniak K., 2002, Ulice grodzieńskie w broszurze Jodkowskiego z roku 1931, [в:] M. Kondratiuk (red.), Polsko-białoruskie zwiazki jezykowe, literackie i kulturowe, т. IV, c. 81-100, Białystok.

\section{Источники}

Указание Брестской городской рады о благоустройстве гор. Бреста; Регламент Брестской городской бойни и устав водопроводно-канализачионных редприятий (14 августа 1919 г.), Государственный архив Брестской области (далее ГАБО), Ф. Р-5, оп. 1, д. 4, на 42 листах;

Выписка из протокола заседания Высоко-Литовского магистрата, инструкция о ревизии гмин и списки населенных пунктов Брестского повета. List zaadresowany Do Pana Starosty pow. Brzeskiego (30 I/23 r.). W odpowiedzi na pismo z dnia 23/I r.b. NIV-303/I Wydziat Gospodarczy przy Magistracie m. Brześcia, poniżej tego przesyła wykaz ulic w m. Brześciu z nowymi $i$ dawnymi nazwami, [в:] ГАБО, Ф. 2, оп. 1, д. 208, л. 43-44;

Заявления жителей города Бреста о вьдаче свидетельств на право владения движимьм и недвижимым имуществом с приложением последних (16 февраля 1921 - 16 октября 1921), [в:] ГАБО, Ф. 5, оп. 1, д. 22, на 224 листах;

Протоколь опроса свидетелей по установлению постоянного местожительства граждан гор. Бреста (13.07-27.07.1922), [в:] ГАБО, Ф. 5, оп. 1, д. 25;

Циркулярь, декреть и распоряжения комиссара Брест-Литовского пов. (подлинники и копии) и переписка с ними об открытии торгово-промышленных предприятий, взимании налогов с населения и др. хозяйственным вопросам; сведения о посевах сельскохозяйственньх культур и окрестности гор. Бреста в 1918-1919 ге. Списки коммунальньх предприятий и улии гор. Бреста. Список переименованных магистратом улии г. Бреста с указанием их довоенных названий 26 VI 1919. Wykaz nazw wszystkich ulic w Brześciu Litewskim z wyszczególnieniem zmiany nazw poprzednich na teraźniejsze, [в:] ГАБО, Ф. 5, оп. 1, д. 2, л. 186.

Ogłoszenie Magistratu m. Brześcia o wydawaniu kartek aprowizacyjnych dla ludności izraelickiej od dnia 11 stycznia 1921 r., Объявление Брестского магистрата о выдаче продовольственных карточек жителям города иудейского вероисповедания. Не позднее 11 января 1921 г., [в:] ГАБО, Ф. 5, оп. 1 , д. 108 , л. 40.

Списки улич гор. Бреста владельцев домов и квартир в г. Бресте. (начато 1923 г.-1932 г.), [в:] ГАБО, Ф. 5, оп. 1, д. 2104, л. 1. 
Szkic m. Brześcia N Bugiem „Przedmieście Kijowskie” (Zaludnienie ulic) 1930 r., [в:] ГАБО, Ф. 5, оп. 1, д. 859, л. 2.

Wykaz ulic miasta Brześcia nad Bugiem, [в:] ГАБО, Ф. 5, оп. 1, д. 5419, л. 1.

Orjentacyjny Plan miasta Brześcia n/B., Podziatka 1:15 000 litografia B. Lulkin, Brześć n. B., ul. Jagiellońska 63. Naktad: Kasy Samopomocy Pracowników Szpitala Kolejowego w Brześciu n. B., [inter 1922 et 1939] wraz z indeksem nazw na verso, [online], http://polona.pl/search/83f6a7c0-7331-11e5-843d51949449da13/

Plan miasta Brześcia n/B. 1:10000 [non post 1939], [online], http://polona.pl/ item $/ 22245765 / 0 /$

Plan Brześcia - 1939, [в:] Ващукувна-Каменецка Д., 2000, Брест - город незабываемый, Брест.

Plan miasta Brześcia N/B ze wskazaniem administracyjnych granic ustalonych Rozporzadzeniem Mnisterstwa Spraw Wewnętrznych z dnia 15-XI-1933 r. /Dz.U.R.P. № 93 poz. 716/ Rozporzadzeniem Rady Ministrów z dnia 28-XI-1933 r. /Dz.U.R.P. № 94 poz. 719/ skala 1:10 000, ГАБО, Ф. 5, оп. 1, д. 859, л. 4.

Планъ города БРЕСТ-ЛИТОВСКА Plan Brześcia z 1914 r., [в:] Mondalski W. (red.), 1929, Rocznik Miasta Brześcia na rok 1930, Brześć nad Bugiem.

Mondalski W. (red.), 1929, Rocznik Miasta Brześcia na rok 1930, Brześć nad Bugiem.

Informator miasta Brześcia 1936, Brześć nad Bugiem 1936.

\section{THE URBANONIMICAL SYSTEM OF CITY BREST-ON-THE-BUG BETWEEN THE WARS}

S U M M A R Y

The glorious city Brest during thousands of years somprised of different states, which resulted in the border location. After the Polish-Soviet War Brest became a part of the newly reborn Poland with borders formally recognized by the Treaty of Riga on March 18, 1921. It was renamed in Brest-on-the-Bug on February 12, 1923 in the Second Polish Republic and became the capital of the Polesie Voivodeship in accordance with the pre-1795 tradition.

The street names were collected from both archival and cartographic materials. The most important semantic group contains names with anthroponyms in their structure, which were characteristic and significant for Polish history and culture. Among the names there prevail names of Polish state and war activists (Batorego, Bema, Kilinskiego, Listowskiego, Sobieskiego), Polish national activists (Kościuszki, Pitsudskiego, Traugutta) and Polish writers (Kraszewskiego, Mickiewicza, Orzeszkowej, Rejmonta, Sienkiewicza, Stowackiego). Names of historical events and important for Poland dates are evidence of complicity and dependence on Polish national politics. 
Among the abovementioned names of intraurban objects in Brest-on-the-Bug, structurally presented by complex and simple forms, usually consisting of two components including the nomenclature term ulica (single instances aleja, plac, ścieżka, zautek), we distinguished the following suffixes: - 'a (Rysia, Wronia, Żurawia, etc.), -н- (Browarna, Gimnazjalna, Szpitalna), -н'- (Średnia, Zachodnia, Żytnia), -ова- (Brukowa, Klonowa, Ogrodowa), -ck- (Adamkowska, Kobryńska, Muchawiecka); prefixal forms Nadkolejowa and Zacmentarna. 